\title{
Life History Observations on the Melodious Coqui, Eleutherodactylus wightmanae (Anura: Eleutherodactylidae), from Puerto Rico: Double Clutches and Adult Predation by the Yellow-Chinned Anole, Anolis gundlachi (Squamata: Dactyloidae) ${ }^{1}$
}

\author{
Neftalí Ríos-López ${ }^{2,3}$, Yvonne M. Flores-Rodríguez ${ }^{4}$, Eliacim Agosto- \\ Torres $^{2}$, Coralys Vicéns-López ${ }^{2}$, and Rayza M. Hernández-Muñíz ${ }^{2}$
}

\begin{abstract}
We document the first account of a double clutch in a Puerto Rican frog, the Melodious Coqui, Eleutherodactylus wigthmanae, and adult predation by the anoline lizard, Anolis gundlachi. We discuss our findings in relation to E. wightmanae's reproductive biology, provide insights for future studies on the species, and discuss the role of both species on local food webs.
\end{abstract}

Key Words: Anolis gundlachi, coquis, coquíes, direct development, Eleutherodactylus wightmanae, parental care, predation.

The Melodious Coqui (Anura: Eleutherodactylidae: Eleutherodactylus wightmanae Schmidt, 1920) (Figure 1) is a small-body-size frog (mean snoutvent length or SVL 20.2 mm, Stewart and Woolbright 1996; maximum SVL 23 $\mathrm{mm}$ in females, Hedges et al. 2008; maximum SVL $21.0 \mathrm{~mm}$ in males, Joglar 1998) that can be frequently found close to the ground and in the leaf litter of close-canopy forests throughout all major upland mountain ranges in Puerto Rico (Drewry 1970a, Drewry and Rand 1983, Stewart and Woolbright 1996, Joglar 1998, Ríos-López and Dávila-Casanova 2014). Using evidence based on genetics, acoustics, and body coloration, Hedges et al. (2008) classified this species as part of a small radiation species group that includes the Mountain Coqui (E. portoricensis Schmidt, 1927), the Common Coqui (Eleutherodactylus coqui Thomas, 1966), and the Virgin Islands Coqui (E. schwartzi Thomas, 1966).

Anecdotes refer to Eleutherodactylus wightmanae being abundant in the mid-1960s (Drewry 1970a). The species experienced drastic population declines in eastern Puerto Rico-Sierra de Luquillo mountain range-by mid1990s (Joglar 1998, Angulo 2008). However, E. wightmanae was the second most abundant species in the anuran assemblage (only behind the Common

\footnotetext{
${ }^{1}$ Submitted on June 1, 2015. Accepted on June 10, 2015. Last changes received on July 12, 2015.

${ }^{2}$ Department of Biology, University of Puerto Rico-Humacao, Call Box 860, Humacao, Puerto Rico, USA 00792.

${ }^{3}$ Corresponding author e-mail: neftali.rios@upr.edu, neftalirios@yahoo.edu.

${ }^{4}$ HC-30, Box 35312, San Lorenzo, Puerto Rico, USA 00754. E-mail: bonnie school@ hotmail.com.
} 
Coqui) in each of two upland forests studied during the late-1990s in western Cordillera Central (Vilella and Fogarty 2005). Preliminary population data gathered since early 2014 from the Sierra de Cayey, central-eastern Puerto Rico, seem to support Vilella and Fogarty's results (N. Ríos-López, unpublished data). In addition, Ríos-López and Dávila-Casanova (2014) mentioned that they frequently found E. wightmanae in all 13 upland forests visited, from the Sierra de Cayey to Maricao State Forest in western Cordillera Central. Currently, the IUCN lists the species as endangered (Angulo 2008), but almost nothing is known on its life history, breeding phenology, and population ecology (Joglar 1998, Ríos-López and Dávila-Casanova 2014).

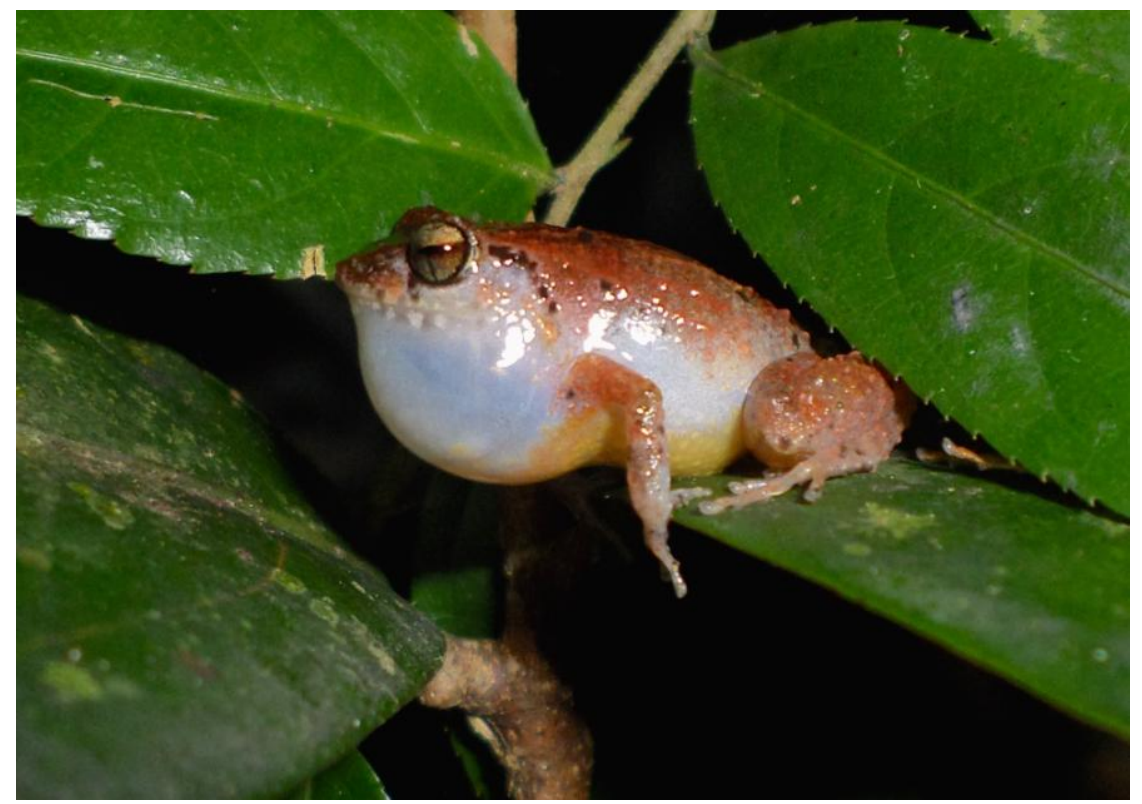

Figure 1. A calling male Eleutherodactylus wightmanae showing its inflated vocal sac in the gular region. Males and females frequently have a yellow-orange ventral coloration (may extend to the gular region in some individuals) on a white colored background, iris coloration golden, pupil shape with ' $\mathrm{T}$ ' pattern, lower mandible with a distinct banding pattern, hind legs with banding pattern (not shown here), and dorsal dark brown-black spots and blotches on a lighter brown to coppery colored background. Photo by N. RíosLópez.

Exceptions to our limited knowledge of the species' life history include data on its diet and generalized feeding habits (Lavigne and Drewry 1970, Stewart and Woolbright 1996), diel acoustic variation (Drewry 1970a, Drewry and Rand 1983), phylogeny (Hedges et al. 2008), and some aspects of its reproductive biology (Joglar et al. 2005, Ríos-López and Dávila-Casanova 2014). Herein we 
document double clutches in single nests, expand our information on its reproductive biology, and document the first predation event for the species.

\section{Methods}

The study area is located in a high elevation forest at the Sierra de Cayey mountains (Cayey-Guayama municipalities, southern Puerto Rico: 18.054405 $\mathrm{N},-66.123019^{\circ} \mathrm{W}$, datum: WGS 84, elev. $=817 \mathrm{~m}$ above sea level). The forest is classified a Mountain Wet Forest on Volcanic Substrate (Lugo 2005), and its average annual rainfall and temperature is $1453 \mathrm{~mm} \mathrm{y}^{-1}$ and $22.9^{\circ} \mathrm{C}$, respectively (long-term data between 1955 and 2001 from weather station Cayey 1E [COOP 681901], National Oceanic and Atmospheric Administration-National Weather Service, San Juan, PR). The predominant vegetation is mostly Sierra Palm (Arecales: Araceae: Prestoea acuminata var. montana [Graham] An. Hend. and Galeano, 1996), which cover $>50 \%$ of higher plants in the study area (RíosLópez and Dávila-Casanova 2014). The species of Eleutherodactylus present at our study site include (in decreasing order of percent abundance of adults; N. Ríos-López, unpubl. data): the Puerto Rican Mountain Coqui (E. portoricensis Schmidt, 1927; 49.1\%), the Melodious Coqui (E. wightmanae; 33.2\%), the Common Coqui (E. coqui; 10.2\%), and the Grass Coqui (E. brittoni Schmidt, $1920 ; 7.6 \%$ ).

In this forest, we established two $20 \times 20 \mathrm{~m}$ plots, approx. $200 \mathrm{~m}$ apart, in June 2013. In each plot we placed 121 plastic tubes (diameter $=23.5 \mathrm{~mm}$; length $=150-170 \mathrm{~mm}$ ) on the forest litter, each tube $2 \mathrm{~m}$ apart from each other, resulting in a grid with tubes located at the corners of each subplot within the plot. The objective of using these plastic tubes was to provide retreat and breeding sites for Eleutherodactylus wightmanae, thus facilitating observation and study of the species' reproductive biology (to date, only one clutch of $E$. wightmanae has been found in the wild with an accompanying male, both inside a curled leaf of the Trumpet Tree or 'Yagrumo' (Rosales; Urticaceae; Cecropia schreberiana Miq., 1853; Joglar et al. 2005). Soon, we found that E. wightmanae adopted these plastic tubes readily for egg laying, parental care, and as retreat sites: we started checking these tubes for clutches in August 2013 and on our second visit in October we found four single clutches already, one of them with a guarding male. Three more visits, between October 2013 and April 2014, yielded nine additional single clutches, two of them with a guarding male, and we decided to initiate systematic monthly censuses for clutches starting on May 2014 to date.

Data collected included the mean number of eggs per single clutch, mean number of egg per double clutch, estimate of developmental period, relative age of embryos between egg masses in a double clutch, mean developmental stage of embryos in double clutches, and percent parental care between single clutches and double clutches in a nest. We define a nest as the place in which a clutch is found, and we define a clutch as a mass of adhered eggs with all embryos in the 
same developmental stage (identification of developmental stage was based on Townsend and Stewart's 1985 staging table for the Common Coqui). Thus, a single nest may contain a single clutch for a one nest-one clutch situation or two clutches (double) for a one nest-two clutches situation. As for parental care (instances of one or two clutches in a nest discovered with a brooding and guarding male), we counted an event of a double clutch with a guarding male as a single observation of parental care instead of two events of parental care for computing purposes of percent parental care. On each of two nests we found a guarding male with his clutch on one census, but he was absent from his clutch on a second consecutive census, and we found a nest with a guarding male on each of two consecutive censuses: we treated each census observation as an independent event for computing purposes of percent parental care. Finally, after testing for equality of variances, we used a two tails, two-sample t-test to assess the difference in the mean number of eggs per mass found in nests with single and double clutches. We adopted a significance level $\alpha \leq 0.05$.

\section{How can we distinguish a clutch of Eleutherodactylus wightmanae from an egg clutch of another sympatric species at the study site?}

We relied on previously collected field and laboratory data from which subsequent field identification of a clutch of Eleutherodactylus wightmanae was reliable. First, the diameter of the tubes was not sufficiently large as to accommodate most individuals of the second largest species in the assemblage, E. portoricensis (male mean SVL $31.6 \pm 2.1 \mathrm{~mm}, n=13$; female mean SVL $31.3 \pm 3.4 \mathrm{~mm}, n=5$ ) (the largest species being $E$. coqui). Nonetheless, we found clutches of E. portoricensis with $19.0 \pm 2.6$ eggs (range 16-21, $n=3$ ) and clutches of $E$. coqui with $23.4 \pm 2.5$ eggs (range $21-27, n=5$ ) inside the plastic tubes. These clutches are approximately three times larger than clutches of $E$. wightmanae (in general, 7 eggs per clutch, range 4-12; clutches described by Ríos-López and Dávila-Casanova [2014] based on the shape of the egg mass). The only species for which information on its clutches is mostly unknown is $E$. brittoni, the smallest species in the assemblage (SVL $17 \mathrm{~mm}$ approximately, Joglar 1998). Joglar (1998) mentioned that preserved gravid females may contain from two to five mature eggs in their oviducts, and on two occasions, recently hatched juveniles were discovered in a terrarium that harbored a mating pair of E. brittoni under laboratory conditions (N. Ríos-López, pers. obs.): two and three juveniles, respectively. We never saw the clutch, which was presumably laid under a garden pot we put in the terrarium, and because of that, it was suggested that the species seems to lay their eggs hidden under the cover of soil debris, within root mats of herbaceous vegetation, or under the cover of rocks and vegetable matter, thus adding to its highly secretive breeding habits (Joglar 1998). Consequently, we were able to identify E. wightmanae's clutches from clutches of other sympatric species by a combination of data: the difference in size of a clutch, general appearance among clutches of sympatric 
species, and location of the clutch in the field (e.g., leaf litter, in bromeliads, arboreal situations). In addition, experience gained from repeated censuses of clutches with instances of guarding males discovered with all sort of shapes of egg masses described already, and photographic evidence of the shape and appearance of most clutches for reference and image examination on a computer, assist us in positive identification of clutches of $E$. wightmanae.

\section{Double Clutch in a Single Nest}

On June 18, 2014 at 1801 h, we found two clutches of Eleutherodactylus wightmanae in a plastic tube (from now on, the "nest"; Figure 2A). These clutches were not found with a guarding male, but we do know that the frequency of finding a guarding male with his clutch in the nest is low (RíosLópez and Dávila-Casanova 2014; see below). The clutches consisted of two masses of eggs, each with embryos in the same stage of development, judging by their external appearance and coloration, but whose embryos within each egg mass were different in appearance and coloration between masses (Figure 2A: left, a younger egg mass with pink-pigmented embryos clearly distinguishable, nine eggs, mean egg diameter of $4.23 \pm 0.15 \mathrm{~mm}$; right, an older egg mass with dark brown-pigmented embryos, six eggs, mean egg diameter of $4.14 \pm 0.17$ $\mathrm{mm})$. The two egg masses in this double clutch were laid in direct contact with each other. Given that the species is not communal (i.e. do not clump clutches in different communal nests as frequently observed in cold-weather aquaticbreeder anurans), we suggest that a single male is the father of the double clutch.

For five clutches (all single) found between May 2014 and April 2015, we discovered them early enough in development (stages 0-5), and either knew hatching dates (for one clutch discovered at stage 4), or discovered their eggs empty in jelly mass with inner egg membranes still visible within (for four clutches discovered between stages 4 and 5), as to estimate developmental period (days) from oviposition to hatching based on Townsend and Stewart's (1986) relationship between temperature and development in embryos of the Common Coqui. For the one clutch found at stage 4, its estimated age in days since oviposition falls between 2 and 2.5 days (Townsend and Stewart 1985). Townsend and Stewart (1986) provided an equation for developmental period in days (Days $=78.2-[2.47 \mathrm{x}$ Temperature, in degrees Celsius $]$ ) for the Common Coqui, and we know that mean ambient temperature between July 2013 and October 2014 is $21.4 \pm 1.0^{\circ} \mathrm{C}$ at our study site. Consequently, a conservative estimate of developmental period for the one clutch found at stage 4 is 27.327.8 days. For the four clutches found between stages 4 and 5, the estimated mean developmental period is $31.8 \pm 2.8$ days, with most of the variation in days attributed to uncertainty of exact hatching date as we were not able to estimate, for instance, the time required for decomposition of the jelly mass and its appearance in time during decomposition. 


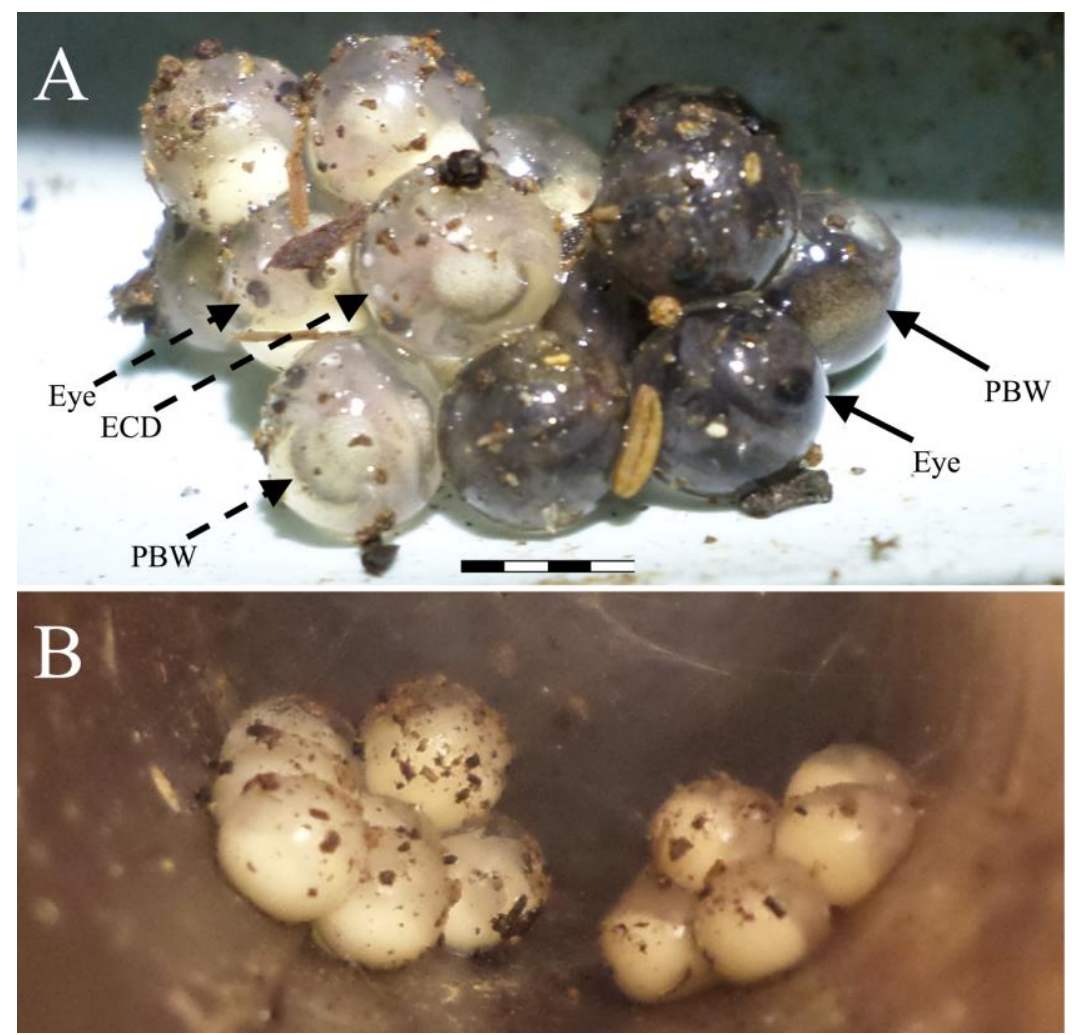

Figure 2. In A, a double clutch in a single nest of Eleutherodactylus wightmanae showing a younger clutch (left egg mass) and an older clutch (right egg mass). Developmental stage of younger embryos is equivalent to stage 7-8 based on Townsend and Stewart's (1985) staging table, with an estimated duration in days (developmental period since oviposition) between 16 and 21 based on Burrowes' (2000) developmental time equivalence for E. cooki. Similarly, developmental stage of older embryos is 13-14, with an estimated duration between 21 and 29 days. Dashed arrows highlight prominent characteristics used for staging embryos, based on Townsend and Stewart's (1985) descriptions: in younger embryos, Eye = iris gray, pupil clear; ECD = endolymphatic calcium deposits as patches quadrangular to triangular in shape with forward extensions partially to rear medial area of eyes; $\mathrm{PBW}=$ pigmented body wall appears as an expanded disc with border even and flanking the trunk between the front and hind limbs. Solid arrows as before, but for older embryos: Eye = iris golden, approaching adult coloration, pupil dark; PBW = pigmented body wall completely encloses yolk; yolk reserve still large and prominent. Scale bar $=4 \mathrm{~mm}$. In B, a double clutch in a single nest of $E$. wightmanae showing two egg masses of similar developmental stage (each in stages between 5 and 6), indicative of oviposition by different females. Egg mass at right slightly dehydrated compared to egg mass at left, judging by its smaller egg diameter and appearance. Photo by N. Ríos-López. 
Nonetheless, the estimated developmental period of clutches in Eleutherodactylus wightmanae is similar to that documented for E. cooki at approximately $360 \mathrm{~m}$ above sea level $(28.7 \pm 2.6$ days; Burrowes 2000$)$ and for E. coqui $(17.1 \pm 0.4$ days $-26.3 \pm 0.9$ days, Townsend and Stewart 1986) at approximately $350 \mathrm{~m}$ above sea level. Townsend and Stewart (1986) revealed that developmental period in inversely related to temperature. Consequently, at an elevation of $817 \mathrm{~m}$ above sea level characterized by a lower temperature in our study site, it may not be surprising the slightly higher developmental period for E. wightmanae compared to that for E. cooki and E. coqui.

Using Townsend and Stewart's (1985) staging table for Eleutherodactylus coqui, Townsend and Stewart's (1986) estimates for developmental period for $E$. coqui, and Burrowes (2000) estimates of days between developmental stages in the Cave-Dwelling Coqui (E. cooki Grant, 1932) we can estimate the relative age in days between two clutches of $E$. wightmanae deposited in the same nest: $4.92 \pm 4.88$ days (range $0-13$ days, $n=10$ ), and $0-8$ developmental stages ( 2.75 \pm 3.0 stages, $n=10$ ). This is slightly lower that mean developmental period between multiple (double and more) clutches in the same nest documented for E. cooki (7 days, range 4-14; Burrowes 2000). However, for a female E. wightmanae, producing energetically costly eggs within an estimated difference in oviposition time between few hours (Figure 2B) and 2 weeks seems highly improbable for several reasons. Firstly, the estimated ovulation period for a female E. coqui-E. wightmanae's closely related species-is approximately 58 days (range 50-71 days, Townsend and Stewart 1994), while that for a female $E$. cooki falls between 30 and 45 days (Burrowes 2000). Secondly, even though female's body size of $E$. wightmanae's is approximately $47 \%$ smaller than $E$. cooki and $50 \%$ smaller than E. coqui, one could suggest that a conservative estimate of ovulation period for a female E. wightmanae might be, at minimum, somewhere between 17.5 days (half the lower ovulation period for $E$. cooki) and 25 days (half the lower ovulation period for E. coqui). Given that we have found double egg clutches with undistinguishable developmental stage of embryos between clutches (Figure 2B), we suggest that double clutches are mostly from different females of $E$. wightmanae. While suggestive, evidence of single paternity and double maternity of double clutches discussed herein may not be definitive as neither have we marked individuals (particularly males) in our study site for identification purposes, nor performed genetic studies to assess these questions. Therefore, a future study may address these questions by sampling genetic material of offspring and potential parents, from different egg clutches in the same nest, and using microsatellite techniques, for example, based on mitochondrial DNA to assess single motherhood and using nuclear DNA to assess single fatherhood.

Parental care of double clutches is $27.3 \%$ (3/11 double clutches). The percent parental care of double clutches is somewhat similar to percent parental care for single clutches, 29.2\% $(n=24)$, documented by Ríos-López and Dávila- 
Casanova (2014). However, we became aware that the increased number of single clutches found between Ríos-López and Dávila-Casanova's (2014) paper (24 clutches) and the present work (55 additional clutches with data on parental care) had a considerable influence on percent parental care in nests for Eleutherodactylus wightmanae: percent parental care of clutches in nests increased from $29.2 \%$ (7/24) to $65.5 \%$ (36/55), revealing a sample-size dependency of the data. Considering our larger data set herein, the percent parental care of E. wightmanae is still 20-30\% smaller compared to parental care in E. cooki $(85.0 \%, n=58$, Joglar et al. 1996) and in E. coqui $(98.2 \%, n=$ 616, Townsend and Stewart 1994).

Double clutches $(n=11)$ represented $13.9 \%$ of nests found from August 2013 to May 2015 ( $n=79$ nests). On average, double clutches had $13.5 \pm 2.9$ eggs in the nest. However, the mean number of eggs per each mass found in a double clutch was $6.7 \pm 2.0$ eggs $(n=22)$, which was not different from the number of eggs in single clutches in a nest, $6.9 \pm 1.6$ eggs $(n=68$ nests $)(t=$ 0.37 , d.f. $=88, p=0.7104$ ). This may suggest that females engaged in a second mating with a guarding male are not more fecund than females engaged in the first mating with the same male.

Comparable data exist on production of multiple clutch nests by other Puerto Rican Eleutherodactylus. Specifically, multiple clutches in nests represent $5.0 \%$ of nests in E. coqui (Townsend et al. 1984), $47.4 \%$ of nests in $E$. cooki (Burrowes 2000), and 16.4\% of nests in the Plains Coqui (E. juanariveroi Ríos-López and Thomas, 2007; Ríos-López et al. 2014). In these species, nests contained triple (all species) and quadruple clutches (only in E. cooki), but we have found only double clutches in nests of E. wightmanae. Nonetheless, production of multiple clutches in nests by these species suggests that males keep calling after gaining a clutch (multiple clutches are also being found from two additional Eleutherodactylus: double clutches in the Hedrick's Coqui, E. hedricki Rivero, 1963 [Drewry 1970b; L. J. Villanueva-Rivera, pers. comm.] and triple clutches in the Whistling Coqui, E. cochranae Grant, 1932 [Joglar 1998; N. Ríos-López, unpubl. data]). This continuing calling effort by males has been interpreted as a strategy that benefits male fitness by reducing missed opportunities for mating while increasing their offspring per unit of time-effort (Townsend et al. 1984, Woolbright 1985, Townsend 1986, Burrowes 2000; for a review on amphibians, see Wells 2007). We must clarify that we do not have sufficient observations on hatching success, nor have we assessed calling effort among males, as to examine whether males guarding double clutches in a nest have a reproductive advantage over males who guard a single clutch. Therefore, a future study may examine the consequences of calling on male fitness in $E$. wightmanae. 


\section{Adult Predation by the Yellow Chinned Anole}

(Squamata: Dactyloidae: Anolis gundlachi Peters, 1876)

On December 14, 2014, at $0355 \mathrm{~h}$, while resting after a census for clutches of Eleutherodactylus wightmanae in our study area (see above), we observed a male Anolis gundlachi (Yellow-Chinned Anole: SVL $57.1 \mathrm{~mm}$; tail length 88.1 $\mathrm{mm})$ that sprinted down a trunk $(8.7 \mathrm{~cm}$ diameter at breast height $)$ of a Sierra Palm (Arecales: Araceae: Prestoea acuminata var. montana [Graham] An. Hend. and Galeano, 1996), dived into the leaf litter, and caught an adult $E$. wightmanae by his head (SVL $22.4 \mathrm{~mm}$; this individual was not calling). We identified the anole species based on a combination of characters that included its body size and habits (trunk-ground anole), and its yellow chin and blue iris (coloration features that, when present in combination, are unique among Puerto Rican anoles). The lizard jumped back to the trunk, and stayed at $10 \mathrm{~cm}$ in height with the frog in its mouth. As we approached the lizard to take a picture, it climbed the trunk to a height of $1.8 \mathrm{~m}$, turned head down the trunk, and revealed the frog in its mouth - the frog was partially ingested up to its thorax (Figure 3). At $0401 \mathrm{~h}$ (approximately two hours before sunset), the lizard climbed even higher on the palm trunk, at approximately $3 \mathrm{~m}$ in height, to finish ingesting the frog. At $0403 \mathrm{~h}$, the lizard rubbed his snout sideways (with the frog still in its mouth) against the surface of the palm trunk as the lizard worked the frog deeper into his mouth for ingestion. At $0405 \mathrm{~h}$, only the hind legs of the frog were visible protruding from the lizard's mouth. At $0422 \mathrm{~h}$, the lizard ingested the frog completely.

Herpetofaunal preys of Anolis gundlachi include lizards (Squamata: Dactyloidae: A. krugi Peters, 1876 [Mountain Garden Anole] and A. stratulus Cope, 1861 [Saddle Anole]; Squamata: Gekkonidae: Sphaerodactylus klauberi Grant, 1931 [Puerto Rican Upland Sphaero]) and anurans (Eleutherodactylus coqui and an unidentified Eleutherodactylus sp.) (reviewed by Henderson and Powell 2009). Reagan (1996a) documented that an Eleutherodactylus frog (unidentified species) was found only in one stomach of a female A. gundlachi (and this is the only reference of an Eleutherodactylus sp. being preyed by this species until now). In addition, Reagan (1996a) also indicated that the vast majority of the prey items found in A. gundlachi were soil litter inhabitants, with prey items found in stomachs of A. gundlachi rarely found on stomachs of other sympatric species occupying different vertical portions of the forest vegetation at El Verde (e.g., Puerto Rican Giant Anole, A. cuvieri Merrem, 1820; Evermann's Anole, A. evermanni Stejneger, 1904; A. stratulus). Herein, we documented A. gundlachi as the first predator identified for E. wightmanae, but this event should not be of surprise for two main reasons: (1) because of $A$. gundlachi's sit-and-wait trunk-ground foraging habits (Reagan 1996a), (2) and the high abundance of E. wightmanae in this Sierra de Cayey forest site set the stage for repeated encounters between two frequent leaf litter foragers and occupants. The occurrences of such predation events are difficult to observe in 
the wild, but we believe that the high abundance of E. wightmanae in the Sierra de Cayey study site likely results in E. wightmanae being depredated by a variety of predators. Tropical islands like Puerto Rico lack the large mammals and predatory species that characterize continents, which makes amphibians and reptiles (along with birds) the most abundant predators regulating local ecosystem energy, carbon, and nutrient flows (Odum et al. 1970; García-Moll 1978; Roughgarden 1995; Reagan 1996a,b; Duellman 1999; Rodda et al. 2001; Beard et al. 2003; Hillman et al. 2009). As such, E. wightmanae and A. gundlachi may be major components of the local food web through predatorprey interactions, particularly during crepuscular hours.

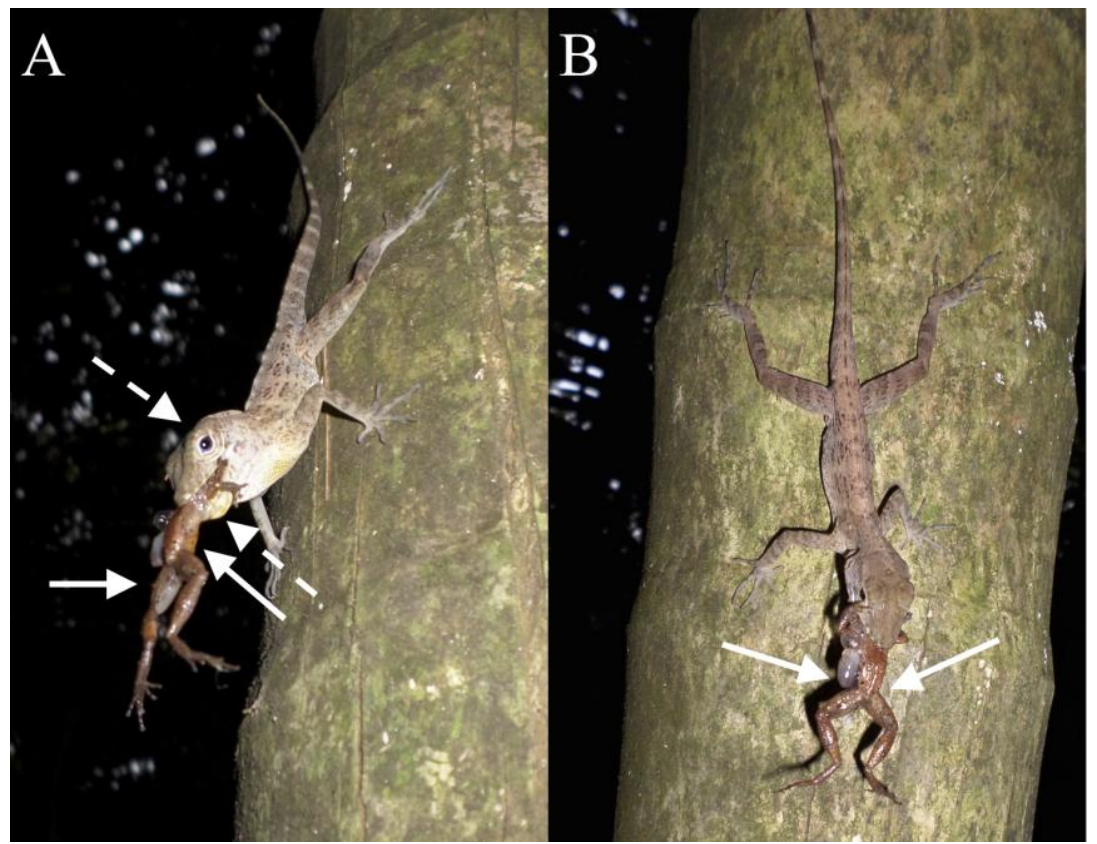

Figure 3. Male Anolis gundlachi eating a male Eleutherodactylus wightmanae headfirst $(\mathrm{A}=$ side view; $\mathrm{B}=$ dorsal view $)$. Identification of $A$. gundlachi was based on a combination of characters (see text): in A, dashed arrows highlight the yellow-colored chin and the blue-colored iris typical of the species. Likewise, identification of the adult E. wightmanae was based on a combination of characters (including its large body size, see text and Figure 1): in A, solid arrows highlight the scarcely visible yellow-orange coloration on the right flank and the colorless inner thigh in $E$. wightmanae (sympatric $E$. portoricensis and E. coqui have intense-to-light tints of orange on this area, respectively; young individuals of both species may show this coloration pattern as well); in B, the mottle coloration pattern towards the distal dorsal region, with dark brown-black blotches on a coppery background (unique coloration pattern among sympatric species in the study site). Also in B, note the exposed inflated tissue on the left flank of E. wightmanae, 
indicative of the rupturing of the frog's abdominal cavity by A. gundlachi. Photo by N. Ríos-López.

\section{Acknowledgments}

We wish to thank five anonymous reviewers for valuable comments that greatly improved this manuscript; W. N. Tirado-Casillas, S. Miranda-Figueroa, G. G. Ma Cao, L. M. Sánchez-Delgado, D. L. Sorando-Rivera, T. Quiles-Delgado, S. M. De León-Santiago, S. Zema, and D. Dávila-Casanova for field assistance; the Department of Natural and Environmental Resources of the Commonwealth of Puerto Rico for issuing permit number 2014-IC-099 (E) (R-VS-PVS15-SJ-00710-24112014).

\section{Literature Cited}

Angulo, A. 2008. Eleutherodactylus wightmanae. The IUCN Red List of Threatened Species. Version 2014.3. <www.iucnredlist.org>. Downloaded on 31 May 2015.

Beard, K. H., A. K. Eschtruth, K. A. Vogt, D. J. Vogt, and F. N. Scatena. 2003. The effects of the frog Eleutherodactylus coqui on invertebrates and ecosystem processes at two scales in the Luquillo Experimental Forest, Puerto Rico. Journal of Tropical Ecology 19:607-617. http://dx.doi.org/10.1017/S0266467403006011

Burrowes, P. A. 2000. Parental care and sexual selection in the Puerto Rican Cave-Dwelling frog, Eleutherodactylus cooki. Herpetologica 56:375-386.

Drewry, G. E. 1970a. Factors affecting activity of rain forest frog populations as measured by electrical recording of sound pressure levels. pp. E55-E68, Chapter E-4. In, Odum, H. T. and R. F. Pigeon (Editors). A Tropical Rain Forest: A Study of Irradiation and Ecology at El Verde, Puerto Rico. U. S. Atomic Energy Commission. Oak Ridge, Tennessee, USA. 1674 pp.

Drewry, G. E. 1970b. The role of amphibians in the ecology of Puerto Rican Rain Forest. pp. 16-63. In, Clements, R. G., G. E. Drewry, and R. J. Lavigne (Editors). The Rain Forest Project Annual Report. June. U. S. Atomic Energy Commission. Oak Ridge, Tennessee, USA. 142 pp. http://dx.doi.org/10.2307/1445095

Drewry, G. E. and A. S. Rand. 1983. Characteristics of an acoustic community: Puerto Rican frogs of the genus Eleutherodactylus. Copeia 1983:941-953. http://dx.doi.org/10.2307/1445095

Duellman, W. E. 1999. The West Indies and Middle America: contrasting origins and diversity. Pp. 357-369. In, Caribbean Amphibians and Reptiles. Crother, B. I. (Editor). Academic Press, Hartcourt Brace and Company. San Diego, California, USA. 495 pp.

García-Moll, A. 1978. Abundance studies on the Anolis lizards and insect populations of altitudinally different tropical forest habitats. Center for Energy and Environment ResearchUniversity of Puerto Rico, Energy Research and Development Administration, U. S. Department of Energy. November 1978: 65 pp.

Hedges, S. B., W. E. Duellman, and M. P. Heinicke. 2008. New World direct-developing frogs (Anura: Terrarana): Molecular phylogeny, classification, biogeography, and conservation. Zootaxa 1737:1-182.

Henderson, R. W. and R. Powell. 2009. Natural History of West Indian Reptiles and Amphibians. University Press of Florida. Gainesville, Florida, USA. 528 pp.

Hillman, S. S., P. C. Withers, R. C. Drewes, and S. D. Hillyard. 2009. Ecological and Environmental Physiology of Amphibians. Oxford University Press. Oxford, England, UK. 469 pp.

Joglar, R. L. 1998. Los Coquies de Puerto Rico: Su Historia Natural y Conservación. Editorial de la Universidad de Puerto Rico. San Juan, Puerto Rico, USA. 232 pp.

Joglar, R. L., P. A. Burrowes, and N. Rios. 1996. Biology of the Puerto Rican cave-dwelling frog, Eleutherodactylus cooki, and some recommendations for its conservqtion. pp. 251-258. In, Powell, R. and R.W. Henderson (Editors). Contributions to West Indian Herpetology: a Tribute to Albert Schwartz. SSAR Contributions to Herpetology (St. Louis, Missouri, USA), Volume 12. 457 pp.

Joglar, R. L., P. A. Burrowes, D. Dávila, A. Rodríguez, A. López, A. Longo, and P. Medina. 2005. Eleutherodactylus wightmanae (Coquí Melodioso), Reproduction. Herpetological Review 36(4):433-434. 
Lavigne, R. J. and G. Drewry. 1970. Feeding behavior of the frogs and lizards in the tropical wet forest. Preliminary report P. R. Nuclear Center. The Rain Forest Project Annual Report. June 1970:64-73.

Lugo, A. E. 2005. Los bosques. pp. 396-545. In, Joglar, R. L. (Editor). Biodiversidad de Puerto Rico: Vertebrados Terrestres y Ecosistemas, Volumen 1. Serie de Historia Natural. Editorial del Instituto de Cultura Puertorriqueña. San Juan, Puerto Rico, USA. 563 pp.

Odum, H. T., G. Drewry, and E. A. McMaham. 1970. Introduction to section E. pp. E3-E15. In, Odum, H. T., and R. F. Pigeon (Editors). A tropical rain forest: A study of irradiation and ecology at El Verde, Puerto Rico. U. S. Atomic Energy Commission. Oak Ridge, Tennessee, USA. 1674 pp.

Reagan, D. P. 1996a. Anoline lizards. pp. 321-345. In, D. P. Reagan and R. W. Waide (Editors). The Food Web of a Tropical Rain Forest. University of Chicago Press. Chicago, Illinois, USA. 616 p.

Reagan, D. P. 1996b. The role of amphibians and reptiles in a West Indian rain forest food web. Pp. 217-227. In, Powell, R. and R. W. Henderson (Editors). Contributions to West Indian Herpetology: A Tribute to Albert Schwartz. Contributions to Herpetology. Volume 12. Society for the Study of Amphibians and Reptiles. Ithaca, New York, USA. 457 pp.

Ríos-López N. and D. Dávila-Casanova. 2014. Eleutherocatylus wightmanae (Melodious Coqui), Reproduction, Parental Care, and Calling Sites. Herpetological Review 45(4):678-679.

Ríos-López, N., M. Reyes-Díaz, L. Ortíz-Rivas, J. E. Negrón-Del Valle, J. E., and C. N. de JesúsVillanueva. 2014. Natural History and Ecology of the Critically Endangered Puerto Rican Plains Coquí, Eleutherodactylus juanariveroi, (Amphibia: Anura: Eleutherodactylidae). Life: The Excitement of Biology 2(2):69-93.

Rodda, G. H., G. Perry, R. J. Rondeau, and J. Lazell. 2001. The densest terrestrial vertebrate. Journal of Tropical Ecology 17:331-338. http://dx.doi.org/10.1017/S0266467401001225

Roughgarden, J. 1995. Anolis lizards of the Caribbean: ecology, evolution, and plate tectonics. Oxford University Press. New York, New York, USA. 226 pp.

Stewart, M. M. and L. L. Woolbright. 1996. Amphibians. Pp. 273-320. In, D. P. Reagan and R. W. Waide (Editors). The Food Web of a Tropical Rain Forest. University of Chicago Press. Chicago, Illinois, USA. 616 pp.

Townsend, D. S. 1986. The costs of male parental care and its evolution in a Neotropical frog. Behavioral Ecology and Sociobiology 19:187-95.

Townsend, D. S. and M. M. Stewart. 1985. Direct development in Eleutherodactylus coqui (Anura: Leptodactylidae): a staging table. Copeia 1985:423-436. http://dx.doi.org/10.2307/1444854

Townsend, D. S. and M. M. Stewart. 1986. The effect of temperature on direct development in a terrestrial-breeding Neotropical frog. Copeia 1986:520-523. http://dx.doi.org/10.2307/1445011

Townsend, D. S. and M. M. Stewart. 1994. Reproductive ecology of the Puerto Rican frog Eleutherodactylus coqui. Journal of Herpetology 28:34-40. http://dx.doi.org/10.2307/1564677

Townsend, D. S., M. M. Stewart, and F. H. Pough. 1984. Male parental care and its adaptive significance in a Neotropical frog. Animal Behaviour 32:421-431. http://dx.doi.org/10.1016/S0003-3472(84)80278-X

Vilella, F. J. and J. H. Fogarty. 2005. Diversity and abundance of forest frogs (Anura: Leptodactylidae) before and after Hurricane Georges in the Cordillera Central of Puerto Rico. Caribbean Journal of Science 41(1):157-162.

Wells, K. D. 2007. The ecology and behavior of amphibians. The University of Chicago Press. Chicago, Illinois, USA. 1148 pp.

Woolbright, L. L. 1985. Patterns of nocturnal movement and calling by the tropical frog Eleutherodactylus coqui. Herpetologica 41:1-9. 